\title{
Grand Challenges! Great Literature?
}

Topics of the Future and Their Consequences for the Past

\author{
Mads Rosendahl Thomsen \\ Aarhus University \\ litmrt@dac.au.dk
}

\begin{abstract}
A changing world has always fed great literature with the dual ambition to thrive on the conflict between old and new worlds while bringing into play all the creativity of literature to frame, redefine, comprehend and criticize with a view to understanding changes in the human condition in its widest sense. Migration, digitalization, climate change and the possible end of humanity as we know it are each in their own way grand challenges to the world. Competing with more media than ever, literature will have to arm itself with expressions that are unique for literature; and fortunately literature's capacity to mix concrete stories and general reflections, to cross time more effortlessly than any other media, and to be rooted in the most distinctive human feature (language) bodes well for this.
\end{abstract}

\section{Keywords}

migration - digital humanities - climate - posthumanism

In his 1987 lecture "Canon and Period," Frank Kermode argues that both canonization and periodization are ways of ordering the past and picking from them what we at present find valuable and interesting (123). There are many indications of the impact of this mechanism, for example the tendency to increasingly privilege prose over poetry in literary studies, not just in the prose-dominated contemporary world, but also in the longer and less prose-orientated past. Current movements and trends in world literature should thus be seen as influences on not only present and future literature, but also the history of world literature.

In Mapping World Literature, I argued that world literature ought to be studied with a clearer perspective on its temporal dimensions $(28-30)$. The 
long past of world literature is very unevenly distributed among nations and languages, with some literatures having many centuries or even millennia of continuous literary activity, whereas others have much shorter pasts to build on. On the other hand, contemporary literature is immensely broad and much less organized into canons, although the process of selection (and forgetting) is continuous and often brutally merciless in its production of oblivion. The future of world literature is closely connected to the process of globalization, in which cultural references blend and intersect more and more, and the expectations of how a literary work is informed by the world will change with this process.

In what follows, I suggest that four current topics that are already making their mark on both reality and fiction have the potential for making a significant impact on the future shape of international circulation of literary works, as well as the continuous canonization of works that circulate as world literature of the past. The four topics are continuing migration and networked identity, the global spread of digital interfaces, climate change, and the challenge to the unity of humanity in the form of a posthuman horizon. Each of these has a particular potential for bridging cultural and local differences as well as providing challenges for literary genres and modes of writing.

\section{Migration and Networked Identity}

Migration is first and foremost an extremely important social and political issue, as witnessed by the thousands of boat refugees that cross the Mediterranean each week from Africa to Europe, the number of Asians involved in the development of African countries, the millions of illegal immigrants working in the USA, and the high-skilled migrants that are moving into the fast-growing centers of capital and cultural production, to mention just a few examples. The many effects of such mass movements affect both receiving and sending nations, and change the perspective for non-migrants as well.

Migration is certainly part of the reason why new ways of thinking of identity have arisen which give a less prominent role to the nation-state. Migration literature has proved to be particularly adept at putting the complexity of identity formation to work in a globalizing world by writing from both sides of a cultural divide that emphasizes the perceptions of mixed affiliations that nonmigrants also experience through changes in their own societies. This change takes place through more and wider travelling, in broader media consumption, and in a change of the general outlook on the world in which the cultural side of globalization supplements national identity building. 
Writers such as Salman Rushdie, Aleksandar Hemon, Teju Cole, and Xiaolu Guo are just a few among a number of authors that have integrated their complex cultural belonging with formal experiments in the form of the novel. Their ability to make amalgamated identity a part of their aesthetic expression while still being accessible to a wide audience has been a significant achievement of this literature in recent decades. Migration literature most often contributes a combination of a positive cosmopolitan world-view with a critical perspective on the drawbacks of migrating. It does so with the ability to approach the world with the moderated strangeness that comes from being neither completely estranged nor completely at home in the world.

It is, for better or worse, also likely that more and more talent will switch language and write in English in order to reach a wider audience, as is the case with Xiaolu Guo and Aleksandar Hemon, for instance. The latter has even suggested that in a few years, people will not notice whether writers are language shifters, even though he himself has made sure that one cannot overlook the bilingualism by using untranslated phrases in his native Bosnian. The same goes for Xiaolu Guo, who in A Concise Chinese-English Dictionary for Lovers includes Chinese writing as well as broken English that improves as her main character picks up the language. Their works are unmistakably works written in English, but with a representation of their migrant background that is used creatively on the level of the language. This is also a characteristic of the Dominican-American writer Junot Díaz, whose The BriefWondrous Life ofOscar Wao includes an abundance of Spanish phrases. Interestingly for the appeal of this mode of writing, Díaz's novel was ranked first in а ввс Culture poll among critics of twenty-first century novels (Flood).

If the rise of migration literature continues to be a tendency in contemporary literature, or even a new world literature as Sigrid Löffler has suggested, it will likely have an effect on literary history and how the dynamics of migration and exile have been a driving force in the evolution of literature. This is of course already documented in Georg Brandes' Main Currents in the Literature of the Nineteenth Century, which places the influence of French migrants front and center:

Exiled Frenchmen were obliged to acquire a more than superficial acquaintance with foreign tongues, if for no other reason, in order to be able to give French lessons in the country of their adoption. It was the intelligent émigré who diffused knowledge of the character and culture of other lands throughout France, and in seeking a general designation for the literary phenomena of this period, it would scarcely be possible to find a better than the one I have adopted: "The Emigrant Literature." 
As migrant experiences increasingly permeate the present day, there will also be a tendency to seek out such experiences of the past, whether it is in lesser known works of African and Asian travel writings of the seventeenth century, as demonstrated in Other Routes: 1500 Years of African and Asian Travel Writing, in the highly canonized but no less émigré works of James Joyce, Samuel Beckett, Paul Celan and Vladimir Nabokov, or in giving rise to a new perspective on world literature, as Rebecca Walkowitz has argued in Born Translated that investigates the complex relations to languages, cultures, nations and markets that a new generation of writers embraces.

\section{Digital Interfaces}

It is evident that the Internet has revolutionized the possibility for communicating and obtaining information, and that this is part of a process that will only continue to gain momentum as more and more people get access to a source of information that is still less than two decades old for most of us. And even though streaming video did not really take off until 2005, many people have grown so accustomed to this option that they can hardly remember the world without immediate access to all sorts of media. Mobile communication has also made a huge impact, with billions of handsets being sold in all parts of the world. One of the most astonishing figures may be that there are now almost as many phones as there are people in Africa, which again has provided a basis for transforming communication and trade.

It is important to notice that it is not just the accessible content that has shifted, but also the form of the various media platforms such as computers and cell phones that is having a huge impact globally. In a few decades all cultures have been given new, strong and evolving media that have become the central apparatuses with which we engage with information, including the production and consumption of literary works. This change is being reinforced by the basic user interfaces with which people spend a significant part of their lives interacting, as well as the commonality of various online services that create a basic common understanding of ways of communicating that did not exist before: the use of Twitter in political struggles, the idea of googling, and the expansion of connections and friendships (and the idea of "friendship") through Facebook and various other social networks. This is just a small selection of ways in which new media have influenced a very significant part of the world's population and given them common platforms that can be used with local content, but where the ways of organizing information and communicating are carriers of the same general way of accessing the world through electronic devices. 
Not surprisingly, there is a growing interest in how literature can explore or enter into a dialogue with new media. One example is the work of Jennifer Egan, whose novel $A$ Visit from the Goon Squad includes representations of PowerPoint slides for a whole chapter. The use of diagrams of all sorts, arrows and slide titles not only narrates the story in a different way, but also makes the reader aware of other ways of thinking and connecting. Egan's experiments continue with her twitter story Black Box (2012), which was published as a series of tweets from the New Yorker's twitter account. ${ }^{1}$ There are numerous other examples of an engagement with new media and the book format, although the book as a medium has proven to be very resilient despite attempts to promote digital literature as the literature of the future.

Another impact comes from the attention to changing media conditions throughout history and how this has shaped literature. The materiality of books has become a much larger subject that is also influencing the attention drawn to works that have something of interest to provide to studies of mediaconscious writers. Studies such as N. Katherine Hayles' How We Think engage with the capacity of literature to explore and change writing in media that is not merely limited to technical changes but is highly dynamic within the history of print media itself. Friedrich Kittler has emphasized how influential media technologies are in shaping human thought and cultures with historical roots and an accelerating influence in the present. And he uses this to cast new light on literary history, for instance in his article "Heinrich van Ofterdingen as Data Feed" on the fragmented novel by Novalis: "The greatest innovation in communications technology that occurred in the Age of Goethe was to combine storage and deletion" (111). This perspective stands out clearly because of our present thinking, but at the same time it adds another layer to the canonical value of the work, enabling Kittler to suggest that the novel does not merely depict actions, but is an act itself (121).

This interest in mediality will tend to privilege literature that stands out as being very conscious of the medium. In some cases this becomes a tale of avant-garde adventures rather than generally interesting literature, as is the case with much so-called digital literature as well as some of the experiments of the historical avant-garde, whose manifestos often read better than their actual works. Because the medium is not the whole message, it is important to be critical of one-dimensional attributions of value to literary works based on their formal experiments alone.

1 Thanks to Tore Rye Andersen, the Center for Literature between Media, Aarhus University, for bringing Egan's work to my attention. 
Another important implication of the attention devoted to various media ecologies with respect to world literature studies is that their differences and their mutual impact constitute a very persuasive and pedagogical way to teach the foundations of literary cultures and make them compatible at a level beyond individual works and very different cultural and historical conditions. David Damrosch's work on the topic presented in "Scriptworlds: Writing Systems and the Formation of World Literature" makes exemplary use of writing systems as the subject and not merely a medium. Tracing the influences of writing systems back for millennia, this story continues today with the multiple influences of expressions spurned by the use of digital media, and the "hero" of this story becomes the collective endeavor of developing and adopting new modes of writing - a narrative that is also crucial in the fictions of Jorge Luis Borges, which in so many ways showed how the consciousness of writing itself can be the central topic for literature. And which is also one of the reasons for the canonical status the Argentinian writer has today.

\section{Climate Changes}

Whereas migration and the digital revolution can be said to have more positive than negative sides in their effort to make the world more open and connected, the effects of climate change are almost all negative, with rising sea levels and temperature increases being two of the most drastic consequences that have (and will have) global effects. Migration will be one consequence of the changed conditions in the seemingly self-defeating era of the Anthropocene. This is also an issue for literature on a number of levels. From postapocalyptic fictions such as J.G. Ballard's works from the 196os like The Wind from Nowhere and more recent works such as David Mitchell's Cloud Atlas, to a whole subgenre of climate fiction (cli-fi), this literature has also become part of a well-established field of research under the umbrella of ecocriticism.

One important aspect of environmental change is that it is an international conflict based not on war between people but on the struggle to cope with the effects of human activity on a scale that goes beyond local interests, and beyond local or national cultural spheres. The challenges of climate change go beyond cultural backgrounds and provide a point of shared reference; and as Lawrence Buell, Ursula K. Heise and Karen L. Thornber remark, one of the most exciting aspects of ecocriticism is an increased interest in non-Western literatures (426). All three critics have themselves contributed to expanding the interest in literature and the environment beyond Western literature with Thornber's 
Ecoambiguity as the most comprehensive study of the interest of East Asian literatures in human relations with nature. Thornber's book demonstrates the ability to relate to issues of environmental concern across the divide of cultural otherness, because the essential effects of pollution and exploitation are easy to understand. But this is framed in a world-view that is both different from the Western perspective as well as being put under pressure by the changes (e.g. $177 \mathrm{ff}$.).

Again, the interest in present-day issues plays a part in shaping interests in the past. Environmental awareness in early industrial-age writing is one example, just as the forces of nature that are unleashed in for example The Epic of Gilgamesh are obvious points worth thematizing in the light of the concerns of our age. It may not be a theme that will drag forgotten writers to prominence, but it will change the perception of a number of writers who have dealt with nature as humanity's otherness; and the environment provides a point of comparison where works can meet across great distance in time and space, but influenced by the same rise in sea levels and temperatures.

\section{The Posthuman Horizon}

While climate change is a serious threat to both the ecological and societal order of the world, it does not change radically the idea of the human or propose a future fundamental change in what it means to be human. Only a few decades ago, it would have been unlikely to see a history of the human species end with a lengthy chapter on the various ways in which humanity could be made responsible for creating its own replacement; but this is the case in Yuval Noah Harari's Sapiens: A Brief History of Humankind from 2014. Harari ends his chronicle by introducing a number of disturbing ways in which human biology could be changed and possibly enhanced through chemistry, genetic modification and extended man-machine interaction, with the possibility of artificially made life looming in the background.

In some ways it seems that humans are more disposed to think of the end of the world, an apocalypse, rather than thinking of being supplanted by a species evolved from us. However, with the acceleration of technological and not least biotechnological inventions, it is hard to ignore the possibility that human existence could be very different within not millennia but only centuries or even decades. The opening of a posthuman horizon that has been created by humanity itself is another way in which a universal subject has emerged which is in many ways more unnerving. 
As with the other topics in this article, the posthuman horizon has a deep resonance in literary history in works such as Mary Shelley's Frankenstein or Aldous Huxley's Brave New World, for instance. Both of these novels remain visionary and relevant to the situation that we face today in their presentation of future worlds that are both less and more advanced than the world we inhabit. The capacity of Dr Frankenstein to stitch together organs and bring them to life appears extremely unsophisticated compared to present-day $3^{\mathrm{D}-}$ printed organs and DNA-modified embryos. The crude way of making less developed cloned workers in Huxley's dystopia by taking away oxygen from fetuses is also far from what the world will be like in 2540 , no matter what use technology is put to. On the other hand, these fictions do present us with imagined realities of things we have not seen and may never want to see.

These subjects are also prominent in contemporary writings. Margaret Atwood explores post-apocalyptic scenarios in her three related novels Oryx and Crake, The Year of the Flood and MaddAddam; while Michel Houellebecq speculates on the end of humankind in a grand UNESCO project to make a more benign (and boring) human being in Atomised. They both play on the paradox that being human has become the modern era's self-evident highest value; while the many imperfections of humanity, from its often dubious morality and many self-interests to its frailty and mortality, call for improving the species.

While visions of posthumans are front and center in these works and many others, other writers have a more subdued and marginal approach to the theme which is impossible to disregard. Mo Yan speculates about pills that could advance humanity as well as the technologies that allow for the abortion of unwanted female fetuses (189). Kazuo Ishiguro's Never Let Me Go depicts a world of cloning programs designed to produce organs for the originals (4). In a novel that Don DeLillo is writing on the intersection of a new technological state of being and the possibility that the brains of future generations will de facto make them posthuman (164). And even Marcel Proust alludes to the idea of a future species with a different comprehension of the world:

... like the sort of first isolated individual of a species which does not yet exist but is going to multiply in the future, an individual endowed with a kind of sense which the human race of his generation does not possess. 716 
This perspective opens up new interests in past literature, with its early visions of automatons resonating with artificial intelligence now attracting renewed attention, as well as the fear and fascination of monsters. Interest in Frankenstein has grown significantly in recent years (Ngram Viewer); ${ }^{2}$ with broader ideas of what life is, how humans are connected, and how they may evolve becoming the center of attention. This often comes with surprising and imaginative outcomes such as in Kurt Vonnegut's Galápagos, where the human brain has shrunk in the eons to come because its capacity for thinking did not really create happiness. And Virginia Woolf's Orlando becomes even more relevant when it is juxtaposed with transhumanist visions of unlimited longevity.

With the outlook of a future where humans can imagine evolving into a different species, the loss of the unity of humanity is also now at stake: people who possess the necessary resources could enter a path of enhancement of many kinds, including quests for unlimited longevity. In this situation, literature's ability to confront ideas of perfection and improvement with narratives of the complexity of life and the necessity of having others is crucial. With the unity of humanity at risk, the question of the posthuman emerges as a new and unexpected universal topic in world literature.

\section{Exit}

A changing world has always fed great literature with the dual ambition to thrive on the conflict between old and new worlds while bringing into play all the creativity of literature to frame, redefine, comprehend and criticize with a view to understanding changes in the human condition in its widest sense. Migration, digitalization, climate change and the possible end of humanity as we know it are each in their own way grand challenges to the world. Competing with more media than ever, literature will have to arm itself with expressions that are unique for literature; and fortunately literature's capacity to mix concrete stories and general reflections, to cross time more effortlessly than any other media, and to be rooted in the most distinctive human feature (language) bodes well for this. This need for a future global literature should also mean that past world literature can be reshaped in a meaningful way.

2 The starting page of Google's Ngram Viewer is a comparison of the frequency with which Frankenstein, Albert Einstein and Sherlock Holmes appear in books published in English since 1800 . 


\section{Works Cited}

Atwood, Margaret. Oryx and Crake: A Novel. New York: Nan A. Talese, 2003.

Ballard, J.G. The Wind from Nowhere. New York: Berkley Books, 1962.

Brandes, Georg. Main Currents in Nineteenth Century Literature. New York: Macmillan, 1906.

Buell, Lawrence, Ursula K. Heise and Karen L. Thornber. "Literature and Environment." Annual Review of Environment and Resources 36 (2011), 417-440.

Damrosch, David. "Scriptworlds: Writing Systems and the Formation of World Literature." Modern Language Quarterly 68:2 (2007), 195-219.

DeLillo, Don. The Names. New York: Knopf, 1982.

Egan, Jennifer. A Visit from the Goon Squad. New York: Alfred A. Knopf, 2010.

Flood, Alison. "The Brief Wondrous Life of Oscar Wao declared 21st century's best novel so far." In The Guardian, www.theguardian.com/books/2015/jan/20/brief-wondrous -life-of-oscar-wao-novel-21st-century-best-junot-diaz, January 20, 2015

Google Ngram Viewer. books.google.com/ngrams [accessed May 22, 2015]

Guo, Xiaolu. A Concise Chinese-English Dictionary for Lovers. New York: Nan A. Talese / Doubleday, 2007.

Harari, Yuval Noah. Sapiens: A Brief History of Humankind. New York: Harper, 2015.

Hayles, N. Katherine. How We Think. Chicago, IL: University of Chicago Press, 2012.

Hemon, Aleksandar. Nowhere Man. New York: Nan A. Talese, 2002.

Houellebecq, Michel. The Elementary Particles. New York: Knopf, 2000.

Ishiguro, Kazuo. Never Let Me Go. New York: Knopf, 2005.

Kermode, Frank. History and Value. Oxford: Oxford University Press, 1989.

Kittler, Friedrich A. The Truth of the Technological World. Stanford, CA: Stanford University Press, 2013.

Löffler, Sigrid. Die neue Weltliteratur und ihre grossen Erzähler. Munich: Beck, 2014.

Mitchell, David. Cloud Atlas. New York: Randon House, 2004.

Proust, Marcel. In Search of Lost Time: The Guermantes Way. New York: Modern Library, 1998.

Thomsen, Mads Rosendahl. Mapping World Literature: International Canonization and Transnational Literatures. London: Continuum, 2008.

Thomsen, Mads Rosendahl. The New Human in Literature: Posthuman Visions of Changes in Body, Mind and Society after 19oo. London: Bloomsbury, 2013.

Thornber, Karen L. Ecoambiguity: Environmental Crises and East Asian Literatures. Ann Arbor, MI: The University of Michigan Press, 2012.

Vonnegut, Kurt. Galápagos: A Novel. New York: Delacorte Press / Seymour Lawrence, 1985 .

Walkowitz, Rebecca L. Born Translated: The Contemporary Novel in an Age of World Literature. New York, NY: Columbia University Press, 2015.

Yan, Mo. Shifu, You'll Do Anything for a Laugh. New York: Arcade, 2001. 